\title{
Matrix Metalloproteinases in Diabetic Kidney Disease
}

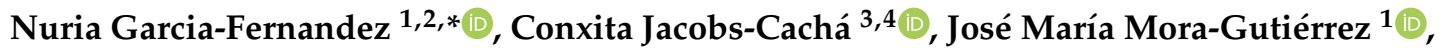 \\ Ander Vergara ${ }^{3,4}$, Josune Orbe ${ }^{2,5}$ (D) and María José Soler ${ }^{3,4, *(D)}$ \\ 1 Nephrology Department, Clinica Universidad de Navarra, 31008 Pamplona, Spain; jmora@unav.es \\ 2 Instituto de Investigación Sanitaria de Navarra (IdiSNA), 31008 Pamplona, Spain; josuneor@unav.es \\ 3 Nephrology Department, Hospital Universitari Vall d'Hebron, Universitat Autònoma de Barcelona, \\ 08007 Barcelona, Spain; conxita.jacobs@vhir.org (C.J.-C.); vergara.ander@gmail.com (A.V.) \\ 4 Nephrology Research Group, Vall d'Hebron Research Institute (VHIR), 08035 Barcelona, Spain \\ 5 Laboratory of Atherothrombosis, Program of Cardiovascular Diseases, Cima-Universidad de Navarra, \\ CIBERCV, 31008 Pamplona, Spain \\ * Correspondence: nrgarcia@unav.es (N.G.-F.); mjsoler01@gmail.com (M.J.S.)
}

Received: 24 December 2019; Accepted: 1 February 2020; Published: 8 February 2020

\begin{abstract}
Around the world diabetic kidney disease (DKD) is the main cause of chronic kidney disease (CKD), which is characterized by mesangial expansion, glomerulosclerosis, tubular atrophy, and interstitial fibrosis. The hallmark of the pathogenesis of DKD is an increased extracellular matrix (ECM) accumulation causing thickening of the glomerular and tubular basement membranes, mesangial expansion, sclerosis, and tubulointerstitial fibrosis. The matrix metalloproteases (MMPs) family are composed of zinc-dependent enzymes involved in the degradation and hydrolysis of ECM components. Several MMPs are expressed in the kidney; nephron compartments, vasculature and connective tissue. Given their important role in DKD, several studies have been performed in patients with DKD proposing that the measurement of their activity in serum or in urine may become in the future markers of early DKD. Studies from diabetic nephropathy experimental models suggest that a balance between MMPs levels and their inhibitors is needed to maintain renal homeostasis. This review focuses in the importance of the MMPs within the kidney and their modifications at the circulation, kidney and urine in patients with DKD. We also cover the most important studies performed in experimental models of diabetes in terms of MMPs levels, renal expression and its down-regulation effect.
\end{abstract}

Keywords: matrix metalloproteinases; diabetic kidney disease; experimental models of diabetes; tissue inhibitors of metalloproteinases

\section{Introduction}

Diabetic kidney disease (DKD) is the main cause of chronic kidney disease (CKD) which is characterized by mesangial expansion, glomerulosclerosis, tubular atrophy, and interstitial fibrosis. Serveral mechanisms such as renin-angiotensin system disbalance, inflammation, proteinuria, and hypertension have been related to DKD progression from the early to the advanced stages of the disease [1].

The trademark of the pathogenesis of DKD is an increased extracellular matrix (ECM) accumulation causing thickening of the glomerular and tubular basement membranes, followed by mesangial expansion, sclerosis, and tubulointerstitial fibrosis. The ECM levels are regulated by a homeostatic balance between deposition and degradation of ECM components [2]. The matrix metalloproteases (MMPs) family are composed of zinc-dependent enzymes that are involved in the degradation and 
hydrolysis of ECM components [3]. The MMPs were discovered in the early 60s and are involved in the collagen degradation processes during the tadpole tail reabsorption [4]. Since then this family of enzymes and their roles have been expanded. Several MMPs are expressed in the kidney; in the nephron compartments, the vasculature and the connective tissue [5,6]. MMPs can contribute to diverse physiologic and pathological pathways in the kidney. Whereas the gelatinases, MMP-2 and MMP-9, have the ability to degrade type IV collagen, the major component of the glomerular basement membrane; the interstitial collagenases, MMP-1, MMP-8 and MMP-13, hydrolyze collagen I and III. Considering their important role in DKD, several studies have been performed in patients with DKD proposing that the measurement of their activity in serum or urine may become in the future markers of early DKD. Studies from diabetic nephropathy (DN) experimental models suggest that a balance between MMPs levels and their inhibitors is needed to maintain renal function.

In this review, we describe the importance of the MMPs family within the kidney and their modifications at the circulation, kidney and urine in patients with DKD. We also cover the most important studies performed in experimental models of diabetes in terms of MMPs levels, renal expression and its inhibition effects.

\section{Matrix Metalloproteinases Family}

MMPs are zinc-dependent proteases that degrade components of the extracellular matrix (ECM). MMPs were initially described as ECM regulatory proteins because of their ability to degrade ECM proteins like collagen, gelatin, laminin, aggrecan, fibronectin, elastin, and proteoglycans [7]. It was later observed that they can also process growth factors, cell-surface receptors, cytokines, and chemokines, as well as other MMPs, and proteases [8]. The activation or inactivation of biomolecules by MMPs cleavage points towards possible unexpected functions of these proteases beyond ECM remodeling [9]. Therefore, MMPs have a relevant physiological function and an altered expression or dysregulation leads to the development of several diseases such as chronic inflammatory diseases, vascular and renal diseases, diabetes, neurological disorders, and cancer $[2,10,11]$.

All MMPs are multidomain enzymes that share a highly conserved core structure. They contain a signal peptide, which directs them to the secretory pathway; a prodomain with a cysteine residue to stabilize and inhibit a conserved HEXGHXXGXXH motif in the catalytic domain; a hinge or linker region; and a hemopexin-like domain that mediate protein-protein interactions and contributes to substrate specificity [7,12]. MMPs are classified into six groups based upon substrate and sequence homology: collagenases, gelatinases, stromelysins, matrilysins, membrane-type MMPs, and "other MMPs" [13-15]. Collagenases (MMP-1, -8, -13, and -18) cleave native collagens I, II, and III at a specific site. Gelatinases (MMP-2 and -9) cleave the denatured collagens (gelatins) and laminin, as well as some chemokines. Stromelysins (MMP-3, -10, -11, and -19) degrade a variety of substrates, including fibronectin, laminin, gelatin, and casein, and can cleave the prodomain of other MMPs activating them [13]. Matrilysins (MMP-7 and -26) are characterized by the lack of a hemopexin domain [15]. MMP-7 degrades not only ECM components such as laminin but also a large number of cell surface molecules, such as E-cadherin, Fas ligand and pro- $\alpha$-defensin. Membrane-type MMPs (MT-MMPs; MMP-14, -15, -16, -17, -24, and -25) are structurally similar to the other classes of MMPs but they are anchored to the outside of the cell membrane by a transmembrane domain, or by a glycosylphosphatidylinositol residue [15] (Table 1). The remaining MMPs, MMP- 12, -20, -21, -23, -27, and -28 , which do not fit into any of the above categories, are currently referred as "other MMPs". 
Table 1. Different matrix metalloproteinases (MMPs) implied in diabetic kidney disease (DKD) and their inhibitors. MMPs and tissue inhibitors of metalloproteinases (TIMPs) expression and characterization is still complex and vary between species.

\begin{tabular}{|c|c|c|c|c|c|}
\hline Group & MMP & Other Names & Molecular Weight & Substrates & Renal Location \\
\hline \multirow[t]{2}{*}{ Collagenases } & MMP-1 & $\begin{array}{l}\text { Interstitial } \\
\text { collagenase }\end{array}$ & $\begin{array}{l}54 \mathrm{kDa} \text {. } \\
\text { Cleaved in different } \\
\text { isoforms that range from } \\
22 \text { to } 27 \mathrm{kDa} \text {. }\end{array}$ & $\begin{array}{l}\text { Type I, II, III, VII and X } \\
\text { collagens. }\end{array}$ & Rats: glomeruli \\
\hline & MMP-13 & Collagenase 3 & $54 \mathrm{kDa}$. & $\begin{array}{l}\text { Type I, II, III, IV, X and XIV } \\
\text { collagens and fibronectin. }\end{array}$ & Rats: glomeruli. \\
\hline \multirow[t]{2}{*}{ Gelatinases } & MMP-2 & Gelatinase A & $\begin{array}{l}\text { Range from } 65 \text { to } 72 \mathrm{kDa} \text {. } \\
\text { Different isoforms. }\end{array}$ & $\begin{array}{l}\text { Type IV, V, VII and X } \\
\text { collagens, type I gelatin and } \\
\text { elastin. }\end{array}$ & $\begin{array}{c}\text { Rats/Mice: glomeruli, } \\
\text { and proximal and distal } \\
\text { tubules. } \\
\text { Monkey: proximal and } \\
\text { distal tubules. } \\
\text { Human: tubules (in } \\
\text { pathological conditions). }\end{array}$ \\
\hline & MMP-9 & Gelatinase B & $92 \mathrm{kDa}$. & $\begin{array}{l}\text { Type IV and V collagens and } \\
\text { type I and V gelatins. }\end{array}$ & $\begin{array}{l}\text { Rats/Mice: glomeruli and } \\
\text { tubular cells. } \\
\text { Monkey: proximal and } \\
\text { distal tubules. }\end{array}$ \\
\hline \multirow[t]{2}{*}{ Stromelysins } & MMP-3 & Stromelysin-1 & $54 \mathrm{kDa}$. & $\begin{array}{l}\text { Type III, IV, IX and X } \\
\text { collagens, type I, III, IV and } \\
\text { V gelatins, proteoglycans, } \\
\text { fibronectic and laminin. }\end{array}$ & $\begin{array}{l}\text { Rats: glomeruli. } \\
\text { Monkey: proximal and } \\
\text { distal tubules. } \\
\text { Human: glomeruli and } \\
\text { tubules. }\end{array}$ \\
\hline & MMP-10 & Stromelysin-2 & $62 \mathrm{kDa}$ & $\begin{array}{l}\text { Type III, IV and V collagens, } \\
\text { gelatin and elastin. } \\
\text { Enhances tissue } \\
\text { plasminogen activator. }\end{array}$ & $\begin{array}{l}\text { Mice: glomeruli and } \\
\text { juxtaglomerular apparatus. }\end{array}$ \\
\hline Matrilysins & MMP-7 & Matrilysin & $30 \mathrm{kDa}$. & $\begin{array}{l}\text { Type I, III, IV and V gelatins, } \\
\text { proteoglycans, fibronectin, } \\
\text { laminin, E-cadherin and } \\
\text { entactin. }\end{array}$ & $\begin{array}{l}\text { Rats: glomeruli. } \\
\text { Human: distal tubules and } \\
\text { collecting duct (in } \\
\text { pathological conditions). }\end{array}$ \\
\hline \multirow[b]{2}{*}{ Membrane-type MMPs } & MMP-14 & MT1-MMP & $\begin{array}{l}\text { Range from } 40 \text { to } 80 \mathrm{kDa} \text {. } \\
\text { There are membrane and } \\
\text { soluble forms. }\end{array}$ & $\begin{array}{c}\text { Progelatinase A } \\
\text { (pro-MMP-2) and MMP-15. }\end{array}$ & Rats/mice: glomeruli. \\
\hline & MMP-24 & MT5-MMP & $64 \mathrm{kDa}$. & $\begin{array}{c}\text { N-cadherin (CDH2), } \\
\text { progelatinase A } \\
\text { (pro-MMP-2), proteoglycans } \\
\text { and fibronectin. }\end{array}$ & $\begin{array}{l}\text { Human: proximal and distal } \\
\text { tubules, collecting duct and } \\
\text { loop of Henle. }\end{array}$ \\
\hline \multirow{2}{*}{ Other MMPs } & ADAM17 & TACE & $93 \mathrm{kDa}$. & $\begin{array}{c}\text { pro-TNF- } \alpha \text {, pro-HER } \\
\text { ligands and other proligand } \\
\text { substrates. }\end{array}$ & $\begin{array}{l}\text { Human: proximal and distal } \\
\text { tubules (in pathological } \\
\text { conditions). }\end{array}$ \\
\hline & MEP1B & $\begin{array}{l}\text { Meprin A } \\
\text { subunit beta }\end{array}$ & $80 \mathrm{kDa}$. & $\begin{array}{l}\text { Type I and III procollagens, } \\
\text { FGF-19, VEGF-A, IL-1 } \beta, \\
\text { IL-18, ADAM10, E-cadherin } \\
\text { and others }\end{array}$ & $\begin{array}{l}\text { Mice: proximal tubule and } \\
\text { juxtamedullary region. }\end{array}$ \\
\hline \multirow{3}{*}{$\begin{array}{c}\text { Tissue inhibitors of } \\
\text { MMPs }\end{array}$} & TIMP-1 & None & $23 \mathrm{kDa}$. & $\begin{array}{l}\text { Inhibits MMP-1, MMP-2, } \\
\text { MMP-3, MMP-7, MMP-8, } \\
\text { MMP-9, MMP-10, MMP-11, } \\
\text { MMP-12, MMP-13 and } \\
\text { MMP-16. }\end{array}$ & $\begin{array}{l}\text { Rats/mice: glomeruli. } \\
\text { Human: glomeruli and } \\
\text { tubules. }\end{array}$ \\
\hline & TIMP-2 & None & $24 \mathrm{KDa}$. & $\begin{array}{c}\text { Inhibits MMP-1, MMP-2, } \\
\text { MMP-3, MMP-7, MMP-8, } \\
\text { MMP-9, MMP-10, MMP-13, } \\
\text { MMP-14, MMP-15, MMP-16 } \\
\text { and MMP-19 }\end{array}$ & Not clearly defined. \\
\hline & TIMP-3 & None & $24 \mathrm{KDa}$. & $\begin{array}{c}\text { Inhibits MMP-1, MMP-2, } \\
\text { MMP-3, MMP-7, MMP-9, } \\
\text { MMP-13, MMP-14 and } \\
\text { MMP-15. }\end{array}$ & Not clearly defined. \\
\hline
\end{tabular}

MMP: metalloproteinase, MT-MMP: membrane-type metalloproteinase, TACE: tumor necrosis factor-alpha converting enzyme, ADAM: a disintegrin and metalloproteinase, HER: human epidermal growth factor receptor, FGF-19: fibroblast growth factor 19, MEP1B: Meprin A subunit beta, VEGF-A: vascular endothelial growth factor A, IL-1 $\beta$ : interleukin 1 beta, IL-18: interleukin 18, TIMP: tissue inhibitor of metalloproteinases.

The role of MMPs in multiple physiological processes is controlled by different factors. In fact, dysregulation of MMPs has been associated to the development of pathological conditions. Regulation of MMP activity depends on transcriptional, epigenetic, and post-transcriptional mechanisms, proteolytic activation, post-translational modifications and extracellular inhibition [9]. MMPs expression is regulated at the transcriptional level, keeping these enzymes at low levels in normal physiological state. However, MMPs expression is induced in response to different stimuli 
when ECM remodeling is required. In addition, DNA methylation or histone acetylation are epigenetic mechanisms of MMP genes transcription. At the post-transcriptional level, MMP expression can be regulated by modulation of messenger RNA (mRNA) stability and micro RNA (miRNA)-based or maintaining the pro-enzymes in an inactive state [12]. MMPs normally remain inactive due to a "cysteine switch" motif located in the propeptide region that blocks the $\mathrm{Zn}^{2+}$ dependent catalytic region. Diverse proteolytic enzymes (serine proteases, furin, plasmin or even other MMPs) can activate the MMPs [14]. Oxidative stress or nitric oxide (NO) can also activate MMPs by destabilization of the "cysteine switch" resulting in active proMMPs [16]. Finally, the MMPs activity is also controlled by specific endogenous inhibitors such as tissue inhibitors of metalloproteinases (TIMPs). TIMPs share a similar structure to MMPs that fits into the active site of the MMP catalytic domain in 1:1 stoichiometric ratio [11]. Overall, the proteolytic activity of TIMPs depends on the relative concentration of the active enzymes and their inhibitors [17].

\section{Matrix Metalloproteinases Pathways in the Kidney}

Several MMPs are expressed in the kidney; in the nephron compartments, the vasculature and the connective tissue [5,6]. MMPs can contribute to diverse physiologic and pathological pathways in the kidney. Chronic kidney disease (CKD) is characterized by a progressive decline in renal function that end up with fibrosis at a histological level $[18,19]$. The pathological mechanism of fibrosis is complex as a series of molecular events lead to an excess of ECM deposition. In response to noxious stimuli, renal cells (glomerular, tubular, vascular or pre-existing infiltrated cells) secrete profibrotic and proinflammatory molecules that will promote the recruitment of inflammatory cells in a positive feedback mechanism. This inflammatory state leads to epithelial-to-mesenchymal transition (EMT) of the tubular cells, recruitment of fibrocytes and proliferation and dedifferentiation of fibroblasts to myofibroblasts. All these cell types produce and deposit ECM thus contributing actively to fibrosis progression [20-22]. The primary function of the MMPs is to degrade ECM components thus it seems obvious that MMP activation or decrease of TIMPs in the kidney would be beneficial but this relation is not that straightforward. Some studies sustain that down-regulation of MMPs activity or upregulation of TIMPs in the kidney could contribute to fibrosis [23,24]. MMP knockout mice models have shown increased fibrosis and accelerated kidney disease progression [25]. In contrast, several reports have shown that upregulation of MMPs promote fibrosis [5,26-28] maybe due to interaction with overexpressed TIMPs $[27,29]$ or due to the capacity of MMP degradation products to induce EMT $[5,30]$.

In a study performed by Tan et al., they exposed murine tubular epithelial cells to an activated macrophage conditioned medium. They demonstrated that exposure to this medium induced EMT in tubular epithelial cells, and that the use of MMP broad spectrum inhibitor reversed these changes [31]. They also identified that macrophage conditioned medium was rich in MMP-2 and MMP-9. Moreover, MMPs actively contribute to inflammation promoting proinflammatory pathways activation mediated by cytokines cleavage [32] and also MMP degradation products induce infiltration of immune cells [5]. In summary, under physiological conditions a regulated MMP activity is crucial for ECM turnover and tissue homeostasis but in a pathological context most MMPs are upregulated contributing actively to all stages of renal fibrosis progression: inflammation, fibrotic type cells recruitment, stimulation of tubular EMT and ECM production and deposition (Figure 1). 


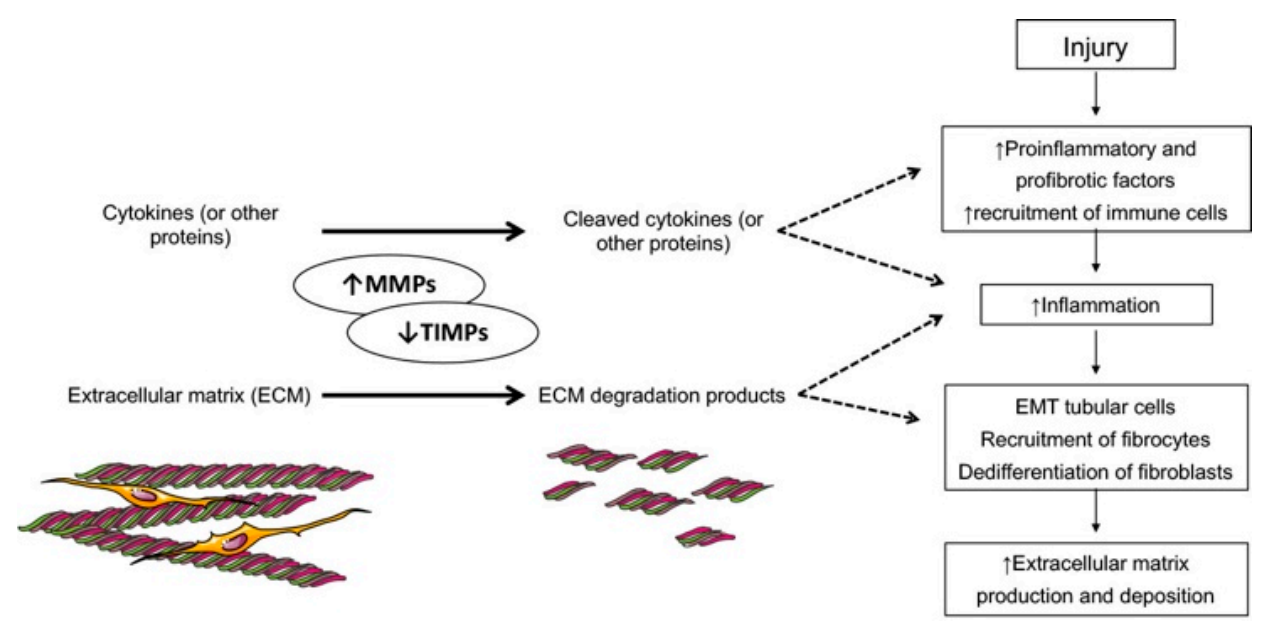

Figure 1. Matrix metalloproteinases/Tissue inhibitors of metalloproteinases (MMPs/TIMP) activity and function in the extracellular matrix turnover. In diabetes the majority of MMPs are upregulated contributing actively to all stages of renal fibrosis formation and progression: inflammation, fibrotic type cell recruitment, stimulation of tubular epithelial-to-mesenchymal transition (EMT) and extracellular matrix (ECM) production and deposition.

\section{MMPs in Human Diabetic Kidney Disease}

The activity of several MMPs is altered in human diabetic kidney disease (DKD). As explained before MMPs are not only involved in ECM remodeling, but also in the release of different growth factors such as tumor necrosis factor $\alpha$ (TNF- $\alpha$ ), transforming growth factor $\beta 1$ (TGF- $\beta 1$ ), and others [33]. Therefore, this protein group dysregulation interferes with normal ECM turnover and may stimulate EMT and fibrosis by increasing the availability of previously mentioned growth factors [34]. In addition, the expression of these endopeptidases has not been well established in human kidney and there are species-dependent differences that hinder the characterization of these proteins (Table 1).

MMP-2 and MMP-9 are two of the proteinases that have been widely studied in human DKD. The concentrations and activity of both proteins are increased in urine of type 1 and 2 diabetic patients [35-37]. The increase in these MMPs is especially frequent in patients with albuminuria, and has been correlated with an established renal injury. However, other studies also demonstrated an increase in MMPs in normoalbuminuric patients that could indicate early renal involvement before the development of proteinuria $[36,38]$. The significance of the increase in plasmatic concentrations of these proteinases is controversial and may be more related to diabetic vascular damage and endothelial dysfunction than to kidney disease. Recently, two different isoforms of MMP-2 have been identified: the full length MMP-2 (FL-MMP-2) and the N-terminal truncated MMP-2 (NTT-MMP-2). The latter is an intracellular isoform and appears to be induced by an alternate promoter located in the first intron that is activated by oxidative stress. It has been related to the activation of the innate immune response and the subsequent inflammation. Expression of these two MMP- 2 isoforms was increased in 25 kidney biopsies of type 2 diabetic patients as compared to healthy controls. Moreover, both proteinases co-localized in affected tubules and have been associated to mononuclear cell infiltration [39]. These findings support previous data where MMP-2 seemed to facilitate EMT and fibrosis by interfering with intercellular connections and releasing TGF- $\beta 1$ [34]. Similarly, another group of MMPs, the stromelysins, have been related to tubular atrophy, interstitial infiltration and fibrosis in DKD. MMP-3 was found inversely correlated with mesangial expansion and glomerular damage, whereas it was increased in tubular atrophy and interstitial lesions [40]. Another proteinase, the MMP-7, is not expressed nor detected in healthy renal tubular epithelium. However, its upregulation has been described in different renal pathological states such as autosomal-dominant polycystic kidney disease and hydronephrosis [41,42]. Interestingly, in a study performed in 121 patients with type 2 diabetes, increased urinary MMP-7 levels were associated with all-cause mortality. However, no clear connection was found between 
these levels and end-stage renal disease (ESRD) development [43]. Other metalloproteinases have also been related to tubular lesions and interstitial fibrosis by releasing profibrotic factors. Among them, enhanced tubular expression of a disintegrin and metalloproteinase protein 17 (ADAM17) has been demonstrated in DN. This proteinase is responsible for TNF- $\alpha$ and amphiregulin (an epidermal growth factor receptor ligand) activation from its proligand substrates [44]. Moreover, the increase in ADAMs serum activity has been independently associated with CKD progression in males and an increased risk of cardiovascular events in CKD patients [45].

Specific MMPs are additionally responsible for other metalloproteinases activation. For instance, pro-MMP-2 is converted into its active form by MMP-24, a membrane-type metalloproteinase also known as MT5-MMP. In human DKD, there is an increased expression of this protein in the tubular epithelium, which correlates with a consequent MMP-2 elevation. Furthermore, proximal, distal and collecting tubules that where positive to MT5-MMP usually showed tubular atrophy as a probable result of DN progression [46]. An additional endopeptidase responsible for pro-MMP-2 activation is the MMP-14, of which membrane and soluble forms had been identified. In patients with type 1 and 2 diabetes these soluble forms are also increased in the urine [37].

TIMPs have also proven to be altered in human DKD. In some studies, circulating concentrations of TIMP-1 and TIMP-2 are decreased in patients with type 2 diabetes and diabetic nephropathy when compared to non-diabetic CKD or patients with diabetes alone [47]. In contrast, increases of serum and urinary concentrations of TIMP-1 were reported in patients with diabetes, and this increase was associated with greater glomerular lesions [48]. The same study that demonstrated increased MMP-3 expression also showed a higher TIMP-1 expression in tubules with atrophy, but both increases inversely correlated with stablished glomerular mesangial expansion [40]. Altogether, interstitial and tubular lesions, which usually correlate with glomerular lesions in DKD, seem more likely to be the source of urinary TIMP-1, as the inhibitor expression decreases in damaged glomeruli.

A greater understanding of kidney MMPs is still needed to better delineate their pathophysiological role in DKD. Although most of these endopeptidases appear to be increased in human DN and apparently related to tubular atrophy and interstitial fibrosis, it is not certain if the activity and concentrations measured in the urine reflect what is really happening in renal tissue or are the consequence of an increased systemic activity [49]. Moreover, it is not yet established if metalloproteinases upregulation precedes fibrosis or if it is a consequence of this lesion. Some studies suggest that MMPs increases antedates the development of albuminuria and, therefore, a more established renal lesion [38,50]. Probably multiple pathological pathways that meet in diabetic nephropathy such as hyperglycemia, advance glycation end products (AGEs), oxidative stress or renin angiotensin system (RAAS) activation are involved in MMPs imbalance. Nevertheless, further MMPs characterization is needed to suggest the use of these proteinases as a possible DKD biomarker or therapeutic target.

\section{MMPs in Experimental Diabetic Nephropathy}

Experimental studies have shown valuable insights into the potential role of MMPs in DN, demonstrating altered expression and enzyme activity in DN rodent models. Evidence supports that MMPs may have both a pathogenic and renoprotective effects. Moreover, the same MMP can play both roles, which underlines the complexity of MMP-system pathobiology [51]. Table 2 summarizes some of the most important experimental studies related to MMP-system performed in experimental models (in vivo and in vitro) of DKD. 
Table 2. Experimental murine studies involving different metalloproteinases.

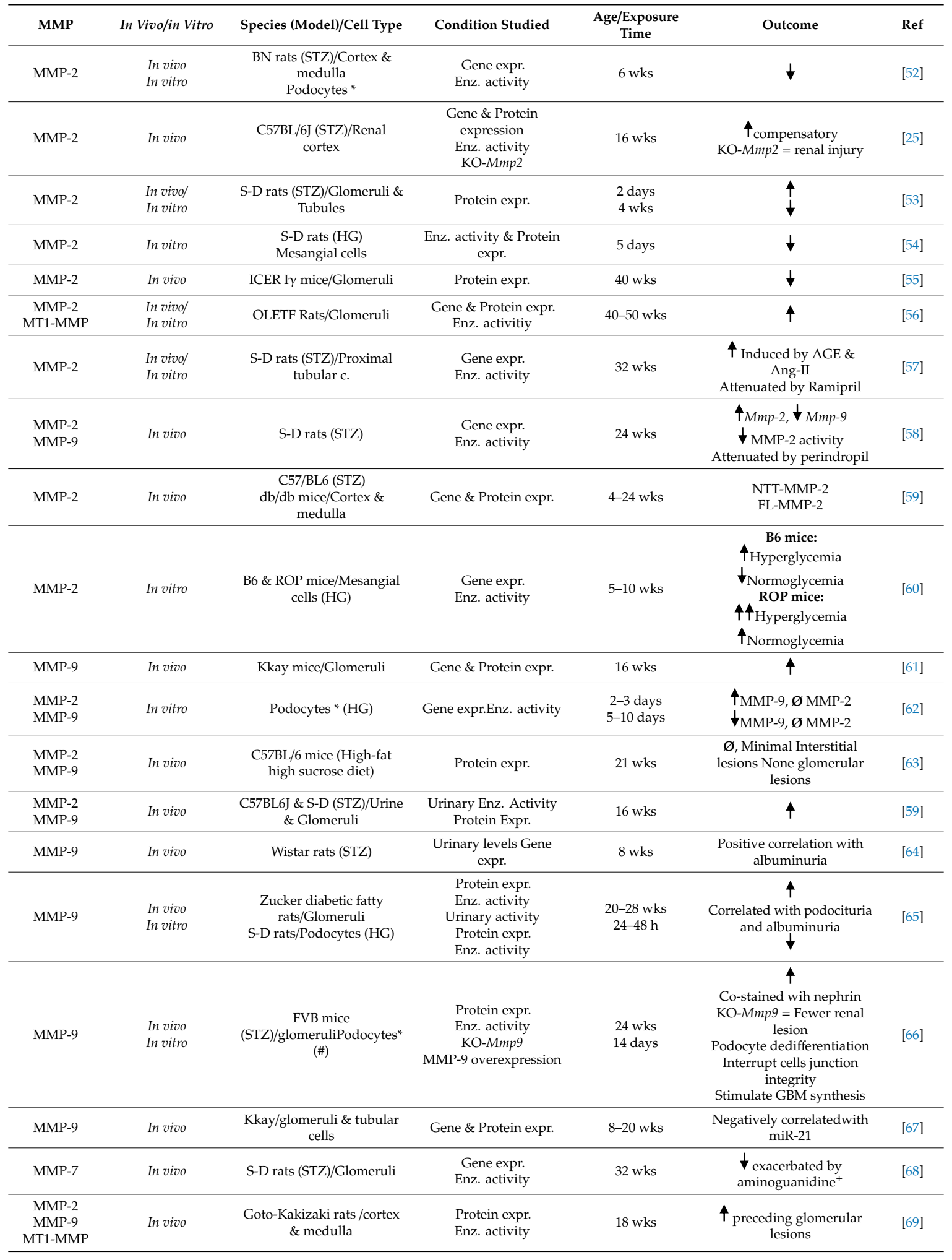


Table 2. Cont.

\begin{tabular}{|c|c|c|c|c|c|c|}
\hline MMP & In Vivo/in Vitro & Species (Model)/Cell Type & Condition Studied & $\begin{array}{l}\text { Age/Exposure } \\
\text { Time }\end{array}$ & Outcome & Ref \\
\hline MT1-MMP & In vivo & S-D rats (STZ)/Glomeruli & $\begin{array}{l}\text { Protein expr. } \\
\text { Inmunogold }\end{array}$ & $4-48$ wks & $\downarrow$ & [70] \\
\hline Meprin & In vivo & C57BL/6 (STZ) & $\begin{array}{l}\text { Gene \& Proteinexpr. } \\
\text { KO-Meprin }\end{array}$ & $\begin{array}{l}12 \mathrm{wks} \\
18 \mathrm{wks}\end{array}$ & $\begin{array}{c}\downarrow \\
\text { KO-Meprin }=\text { renal injury }\end{array}$ & [71] \\
\hline MMP-10 & In vivo & $\begin{array}{l}(\mathrm{db} / \mathrm{db}) / \text { podocytes \& } \\
\text { juxtaglomerular }\end{array}$ & Gene expr. & $8-16$ wks & $\begin{array}{l}\text { 个, attenuated by } \\
\text { telmisartan }\end{array}$ & {$[72]$} \\
\hline MMP-10 & In vivo & C57BL/6 (STZ) & KO-Mmp10 & $17 \mathrm{wks}$ & $\begin{array}{c}\text { KO-Mmp10 = Fewer renal } \\
\text { lesion }\end{array}$ & [73] \\
\hline $\begin{array}{l}\text { MMP-3 } \\
\text { MMP-1 }\end{array}$ & In vivo & S-D rats (STZ)/glomeruli & Gene expr. & $4-24$ wks & $\downarrow$, Prevented by Insulin & {$[74,75]$} \\
\hline MMP-1 & In vivo & $\begin{array}{l}\text { Kunming mice (alloxan) } \\
\text { (BGF) }\end{array}$ & $\begin{array}{l}\text { Gene \& Protein } \\
\text { expression }\end{array}$ & 8 wks & $\downarrow$ & [76] \\
\hline MMP-1 & In vivo & $\begin{array}{c}\text { Albino rats } \\
\text { (alloxan)/circulating levels }\end{array}$ & Serum levels & $14-42$ days & $\downarrow$ & [77] \\
\hline MMP-1 & In vivo & C57BL/6 (STZ)/renal cortex & $M m p 1$ DNA & 28 days & $\begin{array}{c}\text { Prevented diabetic renal } \\
\text { fibrosis }\end{array}$ & [78] \\
\hline \multicolumn{7}{|c|}{$\begin{array}{l}\text { Abbreviations: } \uparrow \text { increase/upregulation, } \downarrow \text { decrease/down-regulation, } \varnothing \text { no changes, BN: Brown Norway, STZ: } \\
\text { streptozotocin-induced diabetes, HG: hyperglycaemia exposure, B6: B6SJLF1/J sclerosis-resistant mice, ROP: ROP/Le- } \\
\text { Es1b/ES1a sclerosis-prone mice, Alloxan: alloxan-induced diabetes, S-D: Sprague-Dawley rats, ICER I } \gamma \text { : ICER I } \gamma \\
\text { transgenic mice, OLETF: Otsuka Long-Evans Tokushima Fatty rats, C57BL/6: C57 black } 6 \text { strain, KO-Mmp2: MMP-2 } \\
\text { knockout mice, FVB: friend leukemia virus B strain, Goto-Kakizaki rats: non-hypertensive model of type } 2 \text { diabetes, } \\
\text { (*) immortalized mouse podocyte cell line, Ang-II: Angiotensin II, gene expr.: gene expression determination, enz. } \\
\text { activity: enzymatic activity determination, wks: weeks, }{ }^{+} \text {aminoguanidine: AGE formation inhibitor, BGF: blood } \\
\text { glucose fluctuation model, \#: podocytes were treated with D-glucose, advanced glycoprotein end-product bovine } \\
\text { serum albumin, angiotensin II, VEGF, TNF-alfa and TGF-beta1. }\end{array}$} \\
\hline
\end{tabular}

Gelatinases (MMP-2 and -9) are the most widely studied MMPs in DN. Early compensatory increases and late decreases in MMP-2 expression and enzymatic activity have been reported in streptozotocin (STZ) diabetic rats [52]. Consistently, Mmp2 null mice worsened renal lesions namely urinary albumin excretion, accumulation of ECM in the glomeruli, atrophy and fibrosis in the tubulointerstitium of STZ-diabetic mice [25]. Han et al. observed an increase in MMP2 expression after 2 days of hyperglycaemia, although after 4 weeks MMP2 expression decreased as a response to the expression of TIMP-2 in glomeruli from Sprague-Dawley (S-D) rats [53]. These results suggest that an imbalance within the MMP-2 and TIMP-2 system, plays an important role in the pathogenesis of diabetic nephropathy. Singh et al. observed, after 5 days of hyperglycaemia, that mesangial cells presented a $25 \%$ reduction in MMP-2 activity, resulting in mesangial matrix accumulation mediated by angiotensin II type 1 (AT1) receptors via TGF- $\beta 1$ [54]. Decreased glomerular MMP-2 expression accompanied augmented collagen-IV expression and glomerulosclerosis in advanced DN [55]. In contrast, increased expression and activity was found in glomeruli of diabetic rats in association with mesangial expansion [56]. Proximal tubular cells also showed enhanced MMP-2 activity induced by advanced glycation end products (AGE) and angiotensin-II [57]. McLennan et al. analysed renal gene expression and activity of MMP-2 and MMP-9 at 24 weeks, observing increased Mmp2 expression but decreased MMP-2 enzymatic activity and Mmp9 down-regulation. These changes were attenuated by renin-angiotensin system (RAS) inhibition [58]. Recently, two different isoforms of MMP-2 were identified in diabetic models showing differentially distribution in renal tissue [59]. An interesting finding on genetic susceptibility to DKD was described by Fornoni et al., who analysed mesangial cells from murine strains resistant (B6) and susceptible (ROP) to sclerosis, mimicking patients who develop DKD despite an adequate glycaemic control. ROP-mice presented basal elevated levels of MMP-2, which increased even more in the presence of hyperglycaemia, although remained elevated when glycaemia was reduced. B6-mice presented an increment on MMP-2 when exposed to hyperglycaemia but returned to baseline levels when glycaemia was normalized. These findings suggest a potential role of MMP-2 in the genetic susceptibility to develop DN [60,79]. Analysing a type 2 diabetes rodent model, it has been shown that renal Mmp9 expression was augmented compared with non-diabetic mice [61]. Bai et al. reported that short- or long-term exposure to hyperglycaemia 
may produce diverse effects on MMP-9. After 2-3 days of hyperglycaemia, an enhanced expression and activity was related with decreased collagen-IV synthesis, while hyperglycaemic-exposure for more than 5 days revealed a down-regulation on MMP-9 expression and activity in podocytes [62]. A recent work, found no differences on MMP-2 and MMP-9 expression in high-fat high sucrose diet-induced diabetes, which presented only minimal interstitial alteration [63]. Urinary MMP-2 and MMP-9 enzymatic activities were increased in type 1 diabetic rodents, and urinary neutrophil gelatinase-associated lipocalin (NGAL)/MMP-9 ratio and MMP-9 activities augmented before the onset of albuminuria [50]. Furthermore, urinary MMP-9 excretion showed positive correlation with albuminuria in diabetic rats, and down-regulation was observed after simvastatin treatment, together with attenuation of glomerular disease [64]. Increased MMP9 staining was observed in glomerular parietal epithelial cells from Zucker diabetic Fatty rats, which was also associated with podocyturia [65]. In fact, increased MMP-9 overexpression and activity induced podocyte dedifferentiation and disruption of junction integrity [66]. MMP-9 has also been inversely correlated with miR-21 expression which plays a role on renal fibrosis on DKD [67].

Referring to matrilysins, McLennan et al. analysed mesangial cells of STZ-induced diabetic rats, observing a down-regulation on MMP-7 expression and increased fibronectin accumulation [68]. Membrane-type MMPs may also play a role in DN. Besides to modulate other MMPs, MT1-MMP (MMP-14) has shown to be up-regulated preceding the manifestation of glomerular pathologic lesions in type 2 diabetic rats [69]; although decreased expression has been reported in glomeruli of long-term diabetic mice [70]. Meprin also seems to have a protective effect on DKD [71]. Relative to stromelysins, our group recently demonstrated glomerular overexpression of MMP10, in podocytes and juxtaglomerular apparatus, in early stages of DN. Interestingly, MMP10 overexpression was prevented with telmisartan administration. These changes were observed despite the absence of significant histological lesions, moreover a correlation was observed between glomerular MMP10 and albuminuria [72]. Consistently, Mmp-10 null diabetic mice presented fewer mesangial expansion, renal macrophage infiltration and renal function impairment [73]. These findings may support a deleterious glomerular effect of MMP-10 on DN, which may be related with the RAS pathway. Another study observed decreased glomerular expression of MMP-3 and MMP-1 in diabetic rats [74]. Unlikely to enalapril [74], insulin treatment ameliorated these changes [75]. MMP-1 expression and serum levels were also down-regulated in alloxan induced-diabetic mice [76,77], while local delivery of Mmp-1 into mice kidneys prevented diabetic renal fibrosis [78].

Analysing the mechanisms by which MMPs may be altered in DN, data suggest that inflammatory pathways may regulate MMPs expression, however some MMPs may also modulate the expression of inflammatory mediators [80]. It has been reported that insulin-like growth factor 1 (ILGF-1) decreases MMP expression [81-83]. TGF- $\beta$ has shown to upregulate MMP-2 [84]. Endothelin also produces an inhibitory effect on MMP-2 and MT1-MMP [85]. Podocyte Vegf f $_{164}$ overexpression down-regulated MMP-2 expression resulting in advanced DN [86]. Hydrogen sulphide enzymes can attenuate MMP-9 expression in the diabetic kidney and mitigate adverse ECM accumulation [87]. IL-20 may play a pathologic role in early DN through upregulation of MMP-9 [88].

Experimental studies have shown that dysregulation of MMPs expression/activity may play a role in DKD through different pathways, underlying the high complexity of the MMP-system. Therefore, in order to understand diverse outcomes from different studies, it is important to take into account: the high homology among MMPs, their diverse locations, diverse substrate specificity, regulators, the discrepancies between in vitro and in vivo models, as well as the different roles they play according to the time of evolution of the diabetes (Table 3). Taken together, MMPs expression and activity may vary in DN, and their pathobiological system is still very confounding. However, an important role seems to be played by both MMPs and their inhibitors in the hallmark of DKD. 
Table 3. Crucial considerations to understand contradictory results when mimicking the experimental outcomes to human studies.

Insulin [89], RAS inhibition [74,81,90], oral antidiabetics [91,92] and diverse pharmacological drugs
[63,93-95] may have an effect on MMPs expression/activity. Murine models based on STZ or
Alloxan-induced diabetes imitate a hypoinsulinemic state (T1D), while those which T2D (db/db,
Kkay, OLETF) are characterized by hyperinsulinism. Moreover, the RAS inhibition is commonly
used in diabetic patients with early DKD. Renin-angiotensin activation could be influenced
according to the murine model employed in the study (hypertension, obesity, salt-intake).
Macrophages infiltration could precede the appearance of DN signs [96]. But also, during diabetes
exists a greater predisposition to urinary tract infections, which may also stimulate macrophage
migration and could be unnoticed if screening analysis or meticulous histological inspection is not
performed. The presence of macrophages due to renal infection may modify the MMPs outcomes of
the study.
II. MMPs expression/activity may vary depending on the type of the renal cell evaluated (i.e.,
proximal/distal tubule, mesangial, podocyte cells) [6]. Also, different conditions and time of
evolution of disease [57] are presented according to in vitro or in vivo models. Moreover, it has been
reported that murine strains may also show certain discrepancies in MMPs outcomes according to
the genetic background [59].
III.
Some MMPs share a great homogeneity, therefore certain molecular techniques may interfere in the
results due to different sensitivities of the assay systems employed [97,98]. For example, MMP-3
shares 82\% homology with MMP-10 at the protein level, which may result in the recognition of both
proteins.

\section{Tissue Inhibitors of Metalloproteinases and Modulators in the Kidney}

TIMPs are specific endogenous inhibitors of metalloproteinases and frequently, their transcriptional regulation is related to MMPs. In fact, MMPs may modulate TIMP signaling by sequestration. Four TIMPs have been identified (TIMP-1, TIMP-2, TIMP-3 and TIMP-4). Although MMPs inhibition is the main role of TIMPs, they can also participate in metalloproteinase activation and, together with MMPs, in other biological processes such as cytokine production, inflammation, migration, cell proliferation and apoptosis [7]. All of these processes have been shown to have potential pathogenic pathways in tissue damage [99]. The role of TIMP in ECM turnover regulation can be different depending on the specific metalloproteinase inhibited and local tissue factors [17]. These multiple functions and complex interactions between TIMPs and MMPs explain how difficult is to define their pathogenic role in different pathologies and diseases [5].

Although renal expression TIMPs has not been completely characterized, all TIMPs, apart from TIMP-4, are expressed in healthy kidney. Human glomeruli express TIMP-1 and TIMP-2, and the upregulation of both has been demonstrated in glomerulosclerosis [100]. Distal convoluted tubular (DCT) expression of TIMP-2 and TIMP-3 has been described in normal kidney [5]. Disregulation of MMPs/TIMPs is implicated in excessive accumulation of ECM in CKD. In fact, suppression of MMP activity and enhanced TIMP expression are associated to fibrosis progression in CKD. Although TIMP-1 overexpression occurs in fibrosis and can promote it independently of MMP inhibition, TIMP-1 deficiency cannot prevent fibrosis due probably to other TIMP compensatory upregulation [101]. TIMPs deletion has suggested a possible protective role of TIMP-3 and fibrotic role of TIMP-2 in renal fibrosis mice models [102].

Dysregulation of MMP/TIMP has been described in clinical studies performed in patients with DKD. In patients with DKD, decreases in serum TIMP-1 and TIMP-2 levels, and increases in serum and urine TIMP-1 levels have been described in association with worsening glomerular lesions [47,72]. In contrast, in experimental DN models, decreases in some MMPs such as MMP-2 [58] and increase 
of TIMP-1 [58] and TIMP-2 expression [53] have been associated to DN progression. TIMP-3 has been found to be down-regulated in diabetic nephropathy and increased TIMP-3 expression shows a renoprotective role for $\mathrm{DN}$ progression [103]. Furthermore, its down-regulation is associated with increased renal fibrosis [6,104].

Potential interventions to attenuate DKD involve increasing MMP-2 activity and TIMP-3 expression and/or inhibiting MMP-9, TIMP-1 and TIMP-2 expression. It has been described the positive effect of the angiotensin-converting enzyme (ACE) inhibitors, estrogens and the peroxisome proliferator-activated receptor- $\gamma$ agonist in TIMP and MMPs in different models of experimental DN. ACE inhibition attenuated MMP-9, decreased TIMP-1 mRNA, and increased TIMP-2 expression in STZ-diabetic rats $[58,105]$. Hepatocyte growth factor (HGF) gene therapy also inhibits TIMP-1 expression in STZ-diabetic rats [106]. Fluorofenidone inhibited TIMP-1 expression in the renal cortex from $\mathrm{db} / \mathrm{db}$ mice (type 2 diabetes) [107]. Dencichine and hyperoside are traditional herbal medicines that ameliorated the renal dysfunction in DN experimental models. Specifically, they increased the MMP-9/TIMP-1 ratio that is exacerbated after the oral dencichine, and subsequently decreases the degradation of ECM [108]. Hyperoside decreased fibrosis by suppressing TIMP-1 expression and promoting MMP-9 expression [109]. Iron chelation by oral deferiprone promoted MMP-9 expression and decreased TIMP-1 in diabetic rats [110]. In addition, berberine decreased MMP-9 and TIMP1/2 levels and increased MMP2 expression in diabetic rats [111]. miR-21 depletion inhibited the progression of DN by promoting TIMP-3 overexpression and inhibiting TIMP-1 expression in STZ-diabetic rats [6,89].

\section{Conclusions}

Taken together MMPs and TIMPs are involved in the development and progression of DN. In patients with diabetes different MMPs such as MMP-2 and MMP-9 are increased in urine, especially in patients with albuminuria and established renal injury. Moreover, it has been speculated that their upregulation may precede early diabetic nephropathy and albuminuria. Research in animal models suggested that the equilibrium between MMPs and its inhibitors is altered in DN. However, experimental studies have also shown contradictory results. These results manifest the complex regulations that exist between different MMPs, TIMPs, and other proinflammatory and profibrotic factors. MMPs and TIMPs probably modify their expression and localization throughout the renal diabetic involvement, and other elements such as drugs or associated pathologies influence these changes, which may help to explain the variability of the observed results to date. Therefore, further studies are needed to improve the characterization and knowledge of MMPs imbalance in diabetic kidney disease.

Author Contributions: N.G.-F., J.M.M.-G., J.O., A.V. and M.J.S. wrote the manuscript and designed the tables. C.J.-C. wrote the manuscript and designed the figure. M.J.S., N.G.-F., A.V. and J.O. reviewed and edited the manuscript. All authors have read and agreed to the published version of the manuscript.

Funding: The authors are current recipients of research grants from the FONDO DE INVESTIGACIÓN SANITARIA-FEDER, ISCIII, PI17/00257, REDINREN, RD16/0009/0030, the Integrated in the State Plan of R + D + I 2016-2018, co-financed by ISCIII, PI 15/02111 and the European Regional Development Fund (FEDER), as well as by the Plan de Investigación Universidad de Navarra (PIUNA) (2014-5).

Acknowledgments: A.V. performed this work within the basis of his thesis at Department de Medicina of Universitat Autònoma de Barcelona (UAB).

Conflicts of Interest: MJS reports conflicts with interest with NovoNordisk, Janssen, Boehringer, Eli Lilly, AstraZeneca, and Esteve. NGF reports conflicts with interest with Boehringer. 


\section{References}

1. Vergara, A.; Jacobs-Cachá, C.; Soler, M.J. Sodium-glucose cotransporter inhibitors: beyond glycaemic control. Clin. Kidney J. 2019, 12, 322-325. [CrossRef] [PubMed]

2. Rodriguez, J.A.; Orbe, J.; De Lizarrondo, S.M.; Calvayrac, O.; Rodriguez, C.; Martinez-Gonzalez, J.; Paramo, J.A. Metalloproteinases and atherothrombosis: MMP-10 mediates vascular remodeling promoted by inflammatory stimuli. Front. Biosci. 2008, 13, 2916-2921. [CrossRef] [PubMed]

3. Altemtam, N.; El Nahas, M.; Johnson, T. Urinary matrix metalloproteinase activity in diabetic kidney disease: a potential marker of disease progression. Nephron Extra 2012, 2, 219-232. [CrossRef] [PubMed]

4. Gross, J.; Lapiere, C.M. Collagenolytic activity in amphibian tissues: A tissue culture assay. Proc. Natl. Acad. Sci. USA. 1962, 48, 1014-1022. [CrossRef]

5. Tan, R.J.; Liu, Y. Matrix metalloproteinases in kidney homeostasis and diseases. Am. J. Physiol.-Renal 2012, 302, F1351-F1361. [CrossRef] [PubMed]

6. Parrish, A.R. Matrix Metalloproteinases in Kidney Disease: Role in Pathogenesis and Potential as a Therapeutic Target. Prog. Mol. Biol. Transl. 2017, 148, 31-65.

7. Nagase, H.; Visse, R.; Murphy, G. Structure and function of matrix metalloproteinases and TIMPs. Cardiovasc. Res. 2006, 69, 562-573. [CrossRef]

8. Marchant, D.J.; Bellac, C.L.; Moraes, T.J.; Wadsworth, S.J.; Dufour, A.; Butler, G.S.; Bilawchuk, L.M.; Hendry, R.G.; Robertson, A.G.; Cheung, C.T.; et al. A new transcriptional role for matrix metalloproteinase-12 in antiviral immunity. Nat. Med. 2014, 20, 493-502. [CrossRef]

9. Page-McCaw, A.; Ewald, A.J.; Werb, Z. Matrix metalloproteinases and the regulation of tissue remodelling. Nat. Rev. Mol. Cell Bio. 2007, 8, 221-233. [CrossRef]

10. Rodríguez, D.; Morrison, C.J.; Overall, C.M. Matrix metalloproteinases: What do they not do? New substrates and biological roles identified by murine models and proteomics. BBA - Mol. Cell Res. 2010, 1803, $39-54$. [CrossRef]

11. Zakiyanov, O.; Kalousová, M.; Zima, T.; Tesař, V. Matrix Metalloproteinases in Renal Diseases: A Critical Appraisal. Kidney Blood Press. Res. 2019, 44, 298-330. [CrossRef] [PubMed]

12. Madzharova, E.; Kastl, P.; Sabino, F.; auf dem Keller, U. Post-Translational Modification-Dependent Activity of Matrix Metalloproteinases. Int. J. Mol. Sci. 2019, 20, 3077. [CrossRef] [PubMed]

13. Fanjul-Fernández, M.; Folgueras, A.R.; Cabrera, S.; López-Otín, C. Matrix metalloproteinases: Evolution, gene regulation and functional analysis in mouse models. BBA-Mol. Cell Res. 2010, 1803, 3-19. [CrossRef] [PubMed]

14. Cui, N.; Hu, M.; Khalil, R.A. Biochemical and Biological Attributes of Matrix Metalloproteinases. Prog. Mol. Biol. Transl. 2017, 147, 1-73.

15. Wang, X.; Khalil, R.A. Matrix Metalloproteinases, Vascular Remodeling, and Vascular Disease. Adv. Pharmacol. 2018, 81, 241-330.

16. Gaffney, J.; Solomonov, I.; Zehorai, E.; Sagi, I. Multilevel regulation of matrix metalloproteinases in tissue homeostasis indicates their molecular specificity in vivo. Matrix Biol. 2015, 44-46, 191-199. [CrossRef]

17. Arpino, V.; Brock, M.; Gill, S.E. The role of TIMPs in regulation of extracellular matrix proteolysis. Matrix Biol. 2015, 44-46, 247-254. [CrossRef]

18. Chen, T.K.; Knicely, D.H.; Grams, M.E. Chronic Kidney Disease Diagnosis and Management: A Review. JAMA 2019, 322, 1294-1304. [CrossRef]

19. Webster, A.C.; Nagler, E.V.; Morton, R.L.; Masson, P. Chronic Kidney Disease. Lancet 2017, 389, $1238-1252$. [CrossRef]

20. Torres, I.B.; Moreso, F.; Sarró, E.; Meseguer, A.; Serón, D. The interplay between inflammation and fibrosis in kidney transplantation. BioMed Res. Int. 2014, 2014, 750602. [CrossRef]

21. Djudjaj, S.; Boor, P. Cellular and molecular mechanisms of kidney fibrosis. Mol. Aspects Med. 2019, 65, 16-36. [CrossRef] [PubMed]

22. Humphreys, B.D. Mechanisms of Renal Fibrosis. Annu. Rev. Physiol. 2018, 80, 309-326. [CrossRef] [PubMed]

23. Lu, Y.; Liu, S.; Zhang, S.; Cai, G.; Jiang, H.; Su, H.; Li, X.; Hong, Q.; Zhang, X.; Chen, X. Tissue inhibitor of metalloproteinase-1 promotes NIH3T3 fibroblast proliferation by activating p-Akt and cell cycle progression. Mol. Cells 2011, 31, 225-230. [CrossRef] [PubMed] 
24. Gagliano, N.; Arosio, B.; Santambrogio, D.; Balestrieri, M.R.; Padoani, G.; Tagliabue, J.; Masson, S.; Vergani, C.; Annoni, G. Age-dependent expression of fibrosis-related genes and collagen deposition in rat kidney cortex. J. Gerontol. A Biol. Sci. Med. Sci. 2000, 55, B365-B372. [CrossRef] [PubMed]

25. Takamiya, Y.; Fukami, K.; Yamagishi, S.; Kaida, Y.; Nakayama, Y.; Obara, N.; Iwatani, R.; Ando, R.; Koike, K.; Matsui, T.; et al. Experimental diabetic nephropathy is accelerated in matrix metalloproteinase-2 knockout mice. Nephrol. Dial. Transplant. 2013, 28, 55-62. [CrossRef] [PubMed]

26. Wang, X.; Zhou, Y.; Tan, R.; Xiong, M.; He, W.; Fang, L.; Wen, P.; Jiang, L.; Yang, J. Mice lacking the matrix metalloproteinase-9 gene reduce renal interstitial fibrosis in obstructive nephropathy. Am. J. Physiol. Renal Physiol. 2010, 299, F973-F982. [CrossRef]

27. Kim, K.M.; Chung, K.W.; Jeong, H.O.; Lee, B.; Kim, D.H.; Park, J.W.; Kim, S.M.; Yu, B.P.; Chung, H.Y. MMP2-A2M interaction increases ECM accumulation in aged rat kidney and its modulation by calorie restriction. Oncotarget 2018, 9, 5588-5599. [CrossRef]

28. Turck, J.; Pollock, A.S.; Leet, L.K.; Marti, H.P.; Lovett, D.H. Matrix metalloproteinase 2 (gelatinase A) regulates glomerular mesangial cell proliferation and differentiation. J. Biol. Chem. 1996, 271, 15074-15083. [CrossRef]

29. Oelusarz, A.; Nichols, L.A.; Grunz-Borgmann, E.A.; Chen, G.; Akintola, A.D.; Catania, J.M.; Burghardt, R.C.; Trzeciakowski, J.P.; Parrish, A.R. Overexpression of MMP-7 Increases Collagen 1A2 in the Aging Kidney. Physiol. Rep. 2013, 1, e00090.

30. Cai, G.; Zhang, X.; Hong, Q.; Shao, F.; Shang, X.; Fu, B.; Feng, Z.; Lin, H.; Wang, J.; Shi, S.; et al. Tissue inhibitor of metalloproteinase- 1 exacerbated renal interstitial fibrosis through enhancing inflammation. Nephrol. Dial. Transplant. 2008, 23, 1861-1875. [CrossRef]

31. Tan, T.K.; Zheng, G.; Hsu, T.-T.; Wang, Y.; Lee, V.W.S.; Tian, X.; Wang, Y.; Cao, Q.; Wang, Y.; Harris, D.C.H. Macrophage matrix metalloproteinase-9 mediates epithelial-mesenchymal transition in vitro in murine renal tubular cells. Am. J. Pathol. 2010, 176, 1256-1270. [CrossRef] [PubMed]

32. Young, D.; Das, N.; Anowai, A.; Dufour, A. Matrix Metalloproteases as Influencers of the Cells' Social Media. Int. J. Mol. Sci. 2019, 20, E3847. [CrossRef] [PubMed]

33. Thrailkill, K.M.; Clay Bunn, R.; Fowlkes, J.L. Matrix metalloproteinases: their potential role in the pathogenesis of diabetic nephropathy. Endocrine 2009, 35, 1-10. [CrossRef] [PubMed]

34. Cheng, S.; Lovett, D.H. Gelatinase A (MMP-2) is necessary and sufficient for renal tubular cell epithelial-mesenchymal transformation. Am. J. Pathol. 2003, 162, 1937-1949. [CrossRef]

35. Thrailkill, K.M.; Bunn, R.C.; Moreau, C.S.; Cockrell, G.E.; Simpson, P.M.; Coleman, H.N.; Frindik, J.P.; Kemp, S.F.; Fowlkes, J.L. Matrix metalloproteinase-2 dysregulation in type 1 diabetes. Diabetes Care 2007, 30, 2321-2326. [CrossRef]

36. Diamant, M.; Hanemaaijer, R.; Verheijen, J.H.; Smit, J.W.A.; Radder, J.K.; Lemkes, H.H. Elevated matrix metalloproteinase-2 and -9 in urine, but not in serum, are markers of type 1 diabetic nephropathy. Diabet. Med. 2001, 18, 423-424.

37. Lauhio, A.; Sorsa, T.; Srinivas, R.; Stenman, M.; Tervahartiala, T.; Stenman, U.H.; Grönhagen-Riska, C.; Honkanen, E. Urinary matrix metalloproteinase $-8,-9,-14$ and their regulators (TRY-1, TRY-2, TATI) in patients with diabetic nephropathy. Ann. Med. 2008, 40, 312-320. [CrossRef]

38. Ebihara, I.; Nakamura, T.; Shimada, N.; Koide, H. Increased plasma metalloproteinase-9 concentrations precede development of microalbuminuria in non-insulin-dependent diabetes mellitus. Am. J. Kidney Dis. 1998, 32, 544-550. [CrossRef]

39. Kim, S.S.; Shin, N.; Bae, S.S.; Lee, M.Y.; Rhee, H.; Kim, I.Y.; Seong, E.Y.; Lee, D.W.; Lee, S.B.; Kwak, I.S.; et al. Enhanced expression of two discrete isoforms of matrix metalloproteinase-2 in experimental and human diabetic nephropathy. PLoS ONE 2017, 12, e0171625. [CrossRef]

40. Suzuki, D.; Miyazaki, M.; Jinde, K.; Koji, T.; Yagame, M.; Endoh, M.; Nomoto, Y.; Sakai, H. In situ hybridization studies of matrix metalloproteinase-3, tissue inhibitor of metalloproteinase-1 and type IV collagen in diabetic nephropathy. Kidney Int. 1997, 52, 111-119. [CrossRef]

41. Surendran, K.; Simon, T.C.; Liapis, H.; McGuire, J.K. Matrilysin (MMP-7) expression in renal tubular damage: Association with Wnt4. Kidney Int. 2004, 65, 2212-2222. [CrossRef] [PubMed]

42. Melk, A.; Mansfield, E.S.; Hsieh, S.C.; Hernandez-Boussard, T.; Grimm, P.; Rayner, D.C.; Halloran, P.F.; Sarwal, M.M. Transcriptional analysis of the molecular basis of human kidney aging using cDNA microarray profiling. Kidney Int. 2005, 68, 2667-2679. [CrossRef] [PubMed] 
43. Afkarian, M.; Zelnick, L.R.; Ruzinski, J.; Kestenbaum, B.; Himmelfarb, J.; De Boer, I.H.; Mehrotra, R. Urine matrix metalloproteinase-7 and risk of kidney disease progression and mortality in type 2 diabetes. J. Diabetes Complications 2015, 29, 1024-1031. [CrossRef] [PubMed]

44. Kefaloyianni, E.; Muthu, M.L.; Kaeppler, J.; Sun, X.; Sabbisetti, V.; Chalaris, A.; Rose-John, S.; Wong, E.; Sagi, I.; Waikar, S.S.; et al. ADAM17 substrate release in proximal tubule drives kidney fibrosis. JCI Insight 2016, 1, 87023. [CrossRef] [PubMed]

45. Palau, V.; Riera, M.; Duran, X.; Valdivielso, J.M.; Betriu, A.; Fernández, E.; Pascual, J.; Soler, M.J. Circulating ADAMs are associated with renal and cardiovascular outcomes in chronic kidney disease patients. Nephrol. Dial. Transplant. 2020, 35, 130-138. [CrossRef]

46. Romanic, A.M.; Burns-Kurtis, C.L.; Ao, Z.; Arleth, A.J.; Ohlstein, E.H. Upregulated expression of human membrane type-5 matrix metalloproteinase in kidneys from diabetic patients. Am. J. Physiol. Renal Physiol. 2001, 281, F309-F317. [CrossRef]

47. Rysz, J.; Banach, M.; Stolarek, R.A.; Pasnik, J.; Cialkowska-Rysz, A.; Koktysz, R.; Piechota, M.; Baj, Z. Serum matrix metalloproteinases MMP-2 and MMP-9 and metalloproteinase tissue inhibitors TIMP-1 and TIMP-2 in diabetic nephropathy. J. Nephrol. 2007, 20, 444-452.

48. Kanauchi, M.; Nishioka, H.; Nakashima, Y.; Hashimoto, T.; Dohi, K. Role of tissue inhibitors of metalloproteinase in diabetic nephropathy. Nihon Jinzo Gakkai Shi. 1996, 38, 124-128.

49. Gudehithlu, K.P.; Garcia-Gomez, I.; Vernik, J.; Brecklin, C.; Kraus, M.; Cimbaluk, D.J.; Hart, P.; Dunea, G.; Arruda, J.A.L.; Singh, A.K. In Diabetic Kidney Disease Urinary Exosomes Better Represent Kidney Specific Protein Alterations Than Whole Urine. Am. J. Nephrol. 2015, 42, 418-424. [CrossRef]

50. McKittrick, I.B.; Bogaert, Y.; Nadeau, K.; Snell-Bergeon, J.; Hull, A.; Jiang, T.; Wang, X.; Levi, M.; Moulton, K.S. Urinary matrix metalloproteinase activities: biomarkers for plaque angiogenesis and nephropathy in diabetes. Am. J. Physiol. Renal Physiol. 2011, 301, F1326-F1333. [CrossRef]

51. Vandenbroucke, R.E.; Libert, C. Is there new hope for therapeutic matrix metalloproteinase inhibition? Nat. Rev. Drug Discov. 2014, 13, 904-927. [CrossRef] [PubMed]

52. Zhang, S.X.; Wang, J.J.; Lu, K.; Mott, R.; Longeras, R.; Ma, J.X. Therapeutic potential of angiostatin in diabetic nephropathy. J. Am. Soc. Nephrol. 2006, 17, 475-486. [CrossRef] [PubMed]

53. Han, S.Y.; Jee, Y.H.; Han, K.H.; Kang, Y.S.; Kim, H.K.; Han, J.Y.; Kim, Y.S.; Cha, D.R. An imbalance between matrix metalloproteinase-2 and tissue inhibitor of matrix metalloproteinase-2 contributes to the development of early diabetic nephropathy. Nephrol. Dial. Transplant. 2006, 21, 2406-2416. [CrossRef] [PubMed]

54. Singh, R.; Alavi, N.; Singh, A.K.; Leehey, D.J. Role of angiotensin II in glucose-induced inhibition of mesangial matrix degradation. Diabetes 1999, 48, 2066-2073. [CrossRef]

55. Inada, A.; Nagai, K.; Arai, H.; Miyazaki, J.I.; Nomura, K.; Kanamori, H.; Toyokuni, S.; Yamada, Y.; Bonner-Weir, S.; Weir, G.C.; et al. Establishment of a diabetic mouse model with progressive diabetic nephropathy. Am. J. Pathol. 2005, 167, 327-336. [CrossRef]

56. Furuichi, K.; Hisada, Y.; Shimizu, M.; Okumura, T.; Kitagawa, K.; Yoshimoto, K.; Iwata, Y.; Yokoyama, H.; Kaneko, S.; Wada, T. Matrix metalloproteinase-2 (MMP-2) and membrane-type 1 MMP (MT1-MMP) affect the remodeling of glomerulosclerosis in diabetic OLETF rats. Nephrol. Dial. Transplant. 2011, 26, 3124-3131. [CrossRef]

57. Fukami, K.; Yamagishi, S.-I.; Coughlan, M.T.; Harcourt, B.E.; Kantharidis, P.; Thallas-Bonke, V.; Okuda, S.; Cooper, M.E.; Forbes, J.M. Ramipril inhibits AGE-RAGE-induced matrix metalloproteinase-2 activation in experimental diabetic nephropathy. Diabetol. Metab. Syndr. 2014, 6, 86. [CrossRef]

58. McLennan, S.V.; Kelly, D.J.; Cox, A.J.; Cao, Z.; Lyons, J.G.; Yue, D.K.; Gilbert, R.E. Decreased matrix degradation in diabetic nephropathy: effects of ACE inhibition on the expression and activities of matrix metalloproteinases. Diabetologia 2002, 45, 268-275. [CrossRef]

59. Kim, I.Y.; Kim, S.S.; Lee, H.W.; Bae, S.S.; Ha, H.K.; Jung, E.S.; Lee, M.Y.; Han, M.; Rhee, H.; Seong, E.Y.; et al. The two isoforms of matrix metalloproteinase- 2 have distinct renal spatial and temporal distributions in murine models of types 1 and 2 diabetes mellitus. BMC Nephrol. 2018, 19, 248. [CrossRef]

60. Fornoni, A.; Striker, L.J.; Zheng, F.; Striker, G.E. Reversibility of glucose-induced changes in mesangial cell extracellular matrix depends on the genetic background. Diabetes 2002, 51, 499-505. [CrossRef]

61. Qing-Hua, G.; Ju-Ming, L.; Chang-Yu, P.; Zhao-Hui, L.; Xiao-Man, Z.; Yi-Ming, M. The kidney expression of matrix metalloproteinase-9 in the diabetic nephropathy of Kkay mice. J. Diabetes Complications. 2008, 22, 408-412. [CrossRef] [PubMed] 
62. Bai, Y.; Wang, L.; Li, Y.; Liu, S.; Li, J.; Wang, H.; Huang, H. High ambient glucose levels modulates the production of MMP-9 and alpha5(IV) collagen by cultured podocytes. Cell Physiol. Biochem. 2006, 17, 57-68. [CrossRef] [PubMed]

63. Dos Santos-Macedo, F.; Martins Gregorio, B.; Cardozo Paes-de-Almeida, E.; de Souza Mendonça, L.; de Souza Azevedo, R.; Fernandes-Santos, C. Kidney osteoclast factors and matrix metalloproteinase expression in a mice model of diet-induced obesity and diabetes. Pathol. Res. Pract. 2019, 215, 152517. [CrossRef] [PubMed]

64. Yao, X.M.; Ye, S.D.; Zai, Z.; Chen, Y.; Li, X.C.; Yang, G.W.; Wang, Y.X.; Chen, K. Simvastatin protects diabetic rats against kidney injury through the suppression of renal matrix metalloproteinase-9 expression. J. Endocrinol. Invest. 2010, 33, 292-296. [CrossRef]

65. Zhang, Y.; George, J.; Li, Y.; Olufade, R.; Zhao, X. Matrix metalloproteinase-9 expression is enhanced in renal parietal epithelial cells of zucker diabetic Fatty rats and is induced by albumin in in vitro primary parietal cell culture. PLoS ONE 2015, 10, e0123276. [CrossRef]

66. Li, S.-Y.; Huang, P.-H.; Yang, A.-H.; Tarng, D.-C.; Yang, W.-C.; Lin, C.-C.; Chen, J.-W.; Schmid-Schönbein, G.; Lin, S.-J. Matrix metalloproteinase-9 deficiency attenuates diabetic nephropathy by modulation of podocyte functions and dedifferentiation. Kidney Int. 2014, 86, 358-369. [CrossRef]

67. Wang, J.; Gao, Y.; Ma, M.; Li, M.; Zou, D.; Yang, J.; Zhu, Z.; Zhao, X. Effect of miR-21 on renal fibrosis by regulating MMP-9 and TIMP1 in kk-ay diabetic nephropathy mice. Cell Biochem. Biophys. 2013, 67, 537-546. [CrossRef]

68. McLennan, S.V.; Kelly, D.J.; Schache, M.; Waltham, M.; Dy, V.; Langham, R.G.; Yue, D.K.; Gilbert, R.E. Advanced glycation end products decrease mesangial cell MMP-7: a role in matrix accumulation in diabetic nephropathy? Kidney Int. 2007, 72, 481-488. [CrossRef]

69. Portik-Dobos, V.; Harris, A.K.; Song, W.; Hutchinson, J.; Johnson, M.H.; Imig, J.D.; Pollock, D.M.; Ergul, A. Endothelin antagonism prevents early EGFR transactivation but not increased matrix metalloproteinase activity in diabetes. Am. J. Physiol. Regul. Integr. Comp. Physiol. 2006, 290, R435-R441. [CrossRef]

70. Boucher, E.; Mayer, G.; Londono, I.; Bendayan, M. Expression and localization of MT1-MMP and furin in the glomerular wall of short- and long-term diabetic rats. Kidney Int. 2006, 69, 1570-1577. [CrossRef]

71. Bylander, J.E.; Ahmed, F.; Conley, S.M.; Mwiza, J.-M.; Ongeri, E.M. Meprin Metalloprotease Deficiency Associated with Higher Mortality Rates and More Severe Diabetic Kidney Injury in Mice with STZ-Induced Type 1 Diabetes. J. Diabetes Res. 2017, 2017, 9035038. [CrossRef] [PubMed]

72. Mora-Gutiérrez, J.; Rodríguez, J.; Férnandez-Seara, M.; Orbe, J.; Escalada, F.; Soler, M.; Slon-Roblero, M.; Riera, M.; Páramo, J.; Garcia-Fernandez, N. High levels of MMP-10 and TIMP-1 in early stage diabetic kidney disease: is there a role for renin-angiotensin system blockade? Sci. Rep. 2020, 8, 26.

73. Toni, M.; Hermida, J.; Goñi, M.J.; Fernández, P.; Parks, W.C.; Toledo, E.; Montes, R.; Díez, N. Matrix metalloproteinase-10 plays an active role in microvascular complications in type 1 diabetic patients. Diabetologia 2013, 56, 2743-2752. [CrossRef] [PubMed]

74. Nakamura, T.; Takahashi, T.; Fukui, M.; Ebihara, I.; Osada, S.; Tomino, Y.; Koide, H. Enalapril attenuated increased gene expression of extracellular matrix components in diabetic rats. J. Am. Soc. Nephrol. 1995, 5, 1492-1497.

75. Nakamura, T.; Fukui, M.; Ebihara, I.; Osada, S.; Tomino, Y.; Koide, H. Abnormal gene expression of matrix metalloproteinases and their inhibitor in glomeruli from diabetic rats. Ren. Physiol. Biochem. 1994, 17, 316-325. [CrossRef]

76. Cheng, X.; Gao, W.; Dang, Y.; Liu, X.; Li, Y.; Peng, X.; Ye, X. Both ERK/MAPK and TGF-Beta/Smad signaling pathways play a role in the kidney fibrosis of diabetic mice accelerated by blood glucose fluctuation. J. Diabetes Res. 2013, 2013, 463740. [CrossRef]

77. Abdel Aziz, M.A.; Badary, D.M.; Hussein, M.R.A. Renal damage following Alloxan-induced diabetes is associated with generation of reactive oxygen species, alterations of p53, TGF- $\beta 1$, and extracellular matrix metalloproteinases in rats. Cell Biol. Int. 2017, 41, 525-533. [CrossRef]

78. Aoyama, T.; Yamamoto, S.; Kanematsu, A.; Ogawa, O.; Tabata, Y. Local delivery of matrix metalloproteinase gene prevents the onset of renal sclerosis in streptozotocin-induced diabetic mice. Tissue Eng. 2003, 9, 1289-1299. [CrossRef]

79. Reckelhoff, J.F.; Tygart, V.L.; Racusen, L.C.; Dzielak, D.J. Glomerular metalloprotease activity in streptozotocintreated rats and in spontaneously diabetic rats (BB/DP). Life Sci. 1994, 55, 941-950. [CrossRef] 
80. Phillips, A.; Steadman, R.; Morrisey, K.; Martin, J.; Eynstone, L.; Williams, J.D. Exposure of human renal proximal tubular cells to glucose leads to accumulation of type IV collagen and fibronectin by decreased degradation. Kidney Int. 1997, 52, 973-984. [CrossRef]

81. Schrijvers, B.F.; De Vriese, A.S.; Flyvbjerg, A. From hyperglycemia to diabetic kidney disease: the role of metabolic, hemodynamic, intracellular factors and growth factors/cytokines. Endocr. Rev. 2004, 25, 971-1010. [CrossRef] [PubMed]

82. Schaefer, L.; Schaefer, R.M.; Ling, H.; Teschner, M.; Heidland, A. Renal proteinases and kidney hypertrophy in experimental diabetes. Diabetologia 1994, 37, 567-571. [CrossRef] [PubMed]

83. Lupia, E.; Elliot, S.J.; Lenz, O.; Zheng, F.; Hattori, M.; Striker, G.E.; Striker, L.J. IGF-1 decreases collagen degradation in diabetic NOD mesangial cells: implications for diabetic nephropathy. Diabetes 1999, 48, 1638-1644. [CrossRef] [PubMed]

84. Marti, H.P.; Lee, L.; Kashgarian, M.; Lovett, D.H. Transforming growth factor-beta 1 stimulates glomerular mesangial cell synthesis of the 72-kd type IV collagenase. Am. J. Pathol. 1994, 144, 82-94.

85. Yao, J.; Morioka, T.; Li, B.; Oite, T. Endothelin is a potent inhibitor of matrix metalloproteinase-2 secretion and activation in rat mesangial cells. Am. J. Physiol. Renal Physiol. 2001, 280, F628-F635. [CrossRef]

86. Veron, D.; Bertuccio, C.A.; Marlier, A.; Reidy, K.; Garcia, A.M.; Jimenez, J.; Velazquez, H.; Kashgarian, M.; Moeckel, G.W.; Tufro, A. Podocyte vascular endothelial growth factor $\left(\operatorname{Vegf}_{164}\right)$ overexpression causes severe nodular glomerulosclerosis in a mouse model of type 1 diabetes. Diabetologia 2011, 54, 1227-1241. [CrossRef]

87. Kundu, S.; Pushpakumar, S.; Sen, U. MMP-9- and NMDA receptor-mediated mechanism of diabetic renovascular remodeling and kidney dysfunction: hydrogen sulfide is a key modulator. Nitric Oxide 2015, 46, 172-185. [CrossRef]

88. Hsu, Y.-H.; Li, H.-H.; Sung, J.-M.; Chen, W.-Y.; Hou, Y.-C.; Weng, Y.-H.; Lai, W.-T.; Wu, C.-H.; Chang, M.-S. Interleukin-20 targets podocytes and is upregulated in experimental murine diabetic nephropathy. Exp. Mol. Med. 2017, 49, e310. [CrossRef]

89. Chen, X.; Zhao, L.; Xing, Y.; Lin, B. Down-regulation of microRNA-21 reduces inflammation and podocyte apoptosis in diabetic nephropathy by relieving the repression of TIMP3 expression. Biomed. Pharmacother. 2018, 108, 7-14. [CrossRef]

90. Lenz, O.; Elliot, S.J.; Stetler-Stevenson, W.G. Matrix metalloproteinases in renal development and disease. J. Am. Soc. Nephrol. 2000, 11, 574-581.

91. Lee, M.P.S.; Sweeney, G. Insulin increases gelatinase activity in rat glomerular mesangial cells via ERK- and PI-3 kinase-dependent signalling. Diabetes Obes. Metab. 2006, 8, 281-288. [CrossRef]

92. Yao, X.; Ye, S.; Chen, Y.; Zai, Z.; Li, X.; Wang, Y.; Chen, K. Rosiglitazone protects diabetic rats against kidney injury through the suppression of renal matrix metalloproteinase-9 expression. Diabetes Obes. Metab. 2009, 11,519-522. [PubMed]

93. Dong, F.; Li, H.; Cai, W.; Tao, J.; Li, Q.; Ruan, Y.; Zheng, F.; Zhang, Z. Effects of pioglitazone on expressions of matrix metalloproteinases 2 and 9 in kidneys of diabetic rats. Chin. Med. J. 2004, 117, 1040-1044. [PubMed]

94. Mankhey, R.W.; Wells, C.C.; Bhatti, F.; Maric, C. 17ß-Estradiol supplementation reduces tubulointerstitial fibrosis by increasing MMP activity in the diabetic kidney. Am. J. Physiol. Regul. Integr. Comp. Physiol. 2007, 292, R769-R777. [CrossRef] [PubMed]

95. Williams, J.M.; Zhang, J.; North, P.; Lacy, S.; Yakes, M.; Dahly-Vernon, A.; Roman, R.J. Evaluation of metalloprotease inhibitors on hypertension and diabetic nephropathy. Am. J. Physiol. Renal Physiol. 2011, 300, F983-F998. [CrossRef] [PubMed]

96. Klessens, C.Q.F.; Zandbergen, M.; Wolterbeek, R.; Bruijn, J.A.; Rabelink, T.J.; Bajema, I.M.; IJpelaar, D.H.T. Macrophages in diabetic nephropathy in patients with type 2 diabetes. Nephrol. Dial. Transplant. 2016, 32, 1322-1329. [CrossRef] [PubMed]

97. Reel, B.; Sala-Newby, G.B.; Huang, W.-C.; Newby, A.C. Diverse patterns of cyclooxygenase-independent metalloproteinase gene regulation in human monocytes. Br. J. Pharmacol. 2011, 163, 1679-1690. [CrossRef]

98. Parks, W.C.; Wilson, C.L.; López-Boado, Y.S. Matrix metalloproteinases as modulators of inflammation and innate immunity. Nat. Rev. Immunol. 2004, 4, 617-629. [CrossRef]

99. Morrison, C.J.; Butler, G.S.; Rodríguez, D.; Overall, C.M. Matrix metalloproteinase proteomics: substrates, targets, and therapy. Curr. Opin. Cell Biol. 2009, 21, 645-653. [CrossRef]

100. Carome, M.A.; Striker, L.J.; Peten, E.P.; Moore, J.; Yang, C.W.; Stetler-Stevenson, W.G.; Striker, G.E. Human glomeruli express TIMP-1 mRNA and TIMP-2 protein and mRNA. Am. J. Physiol. 1993, 264, F923-F929. 
101. Kim, H.; Oda, T.; López-Guisa, J.; Wing, D.; Edwards, D.R.; Soloway, P.D.; Eddy, A.A. TIMP-1 deficiency does not attenuate interstitial fibrosis in obstructive nephropathy. J. Am. Soc. Nephrol. 2001, 12, 736-748. [PubMed]

102. Wang, Z.; Famulski, K.; Lee, J.; Das, S.K.; Wang, X.; Halloran, P.; Oudit, G.Y.; Kassiri, Z. TIMP2 and TIMP3 have divergent roles in early renal tubulointerstitial injury. Kidney Int. 2014, 85, 82-93.

103. Basu, R.; Lee, J.; Wang, Z.; Patel, V.B.; Fan, D.; Das, S.K.; Liu, G.C.; John, R.; Scholey, J.W.; Oudit, G.Y.; et al. Loss of TIMP3 selectively exacerbates diabetic nephropathy. Am. J. Physiol. Renal Physiol. 2012, 303, F1341-F1352. [CrossRef] [PubMed]

104. Kassiri, Z.; Oudit, G.Y.; Kandalam, V.; Awad, A.; Wang, X.; Ziou, X.; Maeda, N.; Herzenberg, A.M.; Scholey, J.W. Loss of TIMP3 Enhances Interstitial Nephritis and Fibrosis. J. Am. Soc. Nephrol. 2009, 20, 1223-1235. [CrossRef]

105. Sun, S.; Wang, Y.; Li, Q.; Tian, Y.; Liu, M.; Yu, Y. Effects of benazepril on renal function and kidney expression of matrix metalloproteinase-2 and tissue inhibitor of metalloproteinase-2 in diabetic rats. Chin. Med. J. 2006, 119, 814-821. [CrossRef]

106. Cruzado, J.M.; Lloberas, N.; Torras, J.; Riera, M.; Fillat, C.; Herrero-Fresneda, I.; Aran, J.M.; Alperovich, G.; Vidal, A.; Grinyo, J.M. Regression of Advanced Diabetic Nephropathy by Hepatocyte Growth Factor Gene Therapy in Rats. Diabetes 2004, 53, 1119-1127. [CrossRef]

107. Wang, L.H.; Liu, J.S.; Ning, W.B.; Yuan, Q.J.; Zhang, F.F.; Peng, Z.Z.; Lu, M.M.; Luo, R.N.; Fu, X.; Hu, G.Y.; et al. Fluorofenidone Attenuates Diabetic Nephropathy and Kidney Fibrosis in db/db Mice. Pharmacology 2011, 88, 88-99. [CrossRef]

108. Jie, L.; Pengcheng, Q.; Qiaoyan, H.; Linlin, B.; Meng, Z.; Fang, W.; Min, J.; Li, Y.; Ya, Z.; Qian, Y.; et al. Dencichine ameliorates kidney injury in induced type II diabetic nephropathy via the TGF- $\beta /$ Smad signalling pathway. Eur. J. Pharmacol. 2017, 812, 196-205. [CrossRef]

109. Zhang, L.; He, S.; Yang, F.; Yu, H.; Xie, W.; Dai, Q.; Zhang, D.; Liu, X.; Zhou, S.; Zhang, K. Hyperoside ameliorates glomerulosclerosis in diabetic nephropathy by downregulating miR-21. Can. J. Physiol. Pharmacol. 2016, 94, 1249-1256. [CrossRef]

110. Zou, C.; Liu, X.; Liu, R.; Wang, M.; Sui, M.; Mu, S.; Li, L.; Ji, L.; Xie, R. Effect of the oral iron chelator deferiprone in diabetic nephropathy rats. J. Diabetes 2017, 9, 332-340. [CrossRef]

111. Ni, W.-J.; Ding, H.-H.; Zhou, H.; Qiu, Y.-Y.; Tang, L.-Q. Renoprotective effects of berberine through regulation of the MMPs/TIMPs system in streptozocin-induced diabetic nephropathy in rats. Eur. J. Pharmacol. 2015, 764, 448-456. [CrossRef] [PubMed] 